\title{
ACVR1 wt Allele
}

National Cancer Institute

\section{Source}

National Cancer Institute. ACVR1 wt Allele. NCI Thesaurus. Code C51721.

Human ACVR1 wild-type allele is located within 2q23-q24 and is approximately $139 \mathrm{~kb}$ in length. This allele, which encodes activin receptor type-1 protein, is involved in transcriptional regulation and signal transduction. 